\title{
PERUBAHAN MINUTA AKTA OLEH NOTARIS SECARA SEPIHAK TANPA SEPENGETAHUAN PENGHADAP
}

\author{
THE CHANGES OF MINUTA DEED \\ BY NOTARY UNILATERALLY
}

\author{
Sri Rahmayani \\ Magister Kenotariatan Universitas Syiah Kuala \\ Email: srirahmayani21@yahoo.co.id \\ Sanusi \\ Universitas Syiah Kuala, Banda Aceh \\ Email: sanusi@unsyiah.ac.id \\ Teuku Abdurrahman \\ Universitas Syiah Kuala, Banda Aceh \\ Email: t.arahmant@yahoo.com
}

\begin{abstract}
This study aims to explain changes in Minuta deeds carried out by notaries unilaterally without the knowledge of one of the viewers; the research method used is normativejuridical method. Data collection techniques are carried out through library research. The data obtained using a qualitative approach. The results showed in some case, which still make the notary into the court, both civil and criminal, under the Decision of the Supreme Court of the Republic of Indonesia Number.42/PDT.G/2013/PN.PBR, Number.606/ PDT/2017/PT.DKI, Number 1003K/PID/2015, and Decision of the Supreme Court of the Republic of Indonesia Number 1099K/PID/2010, which stated that some notaries are not careful about producing a birth deed. As a result, one party experiences a loss that notary made intentionally or unintentionally together with the party / viewers for the purpose to benefit themselves or to harm others. This leads into legal uncertainty for clients or those who intentionally come to a notary in a favor of legal actions. Such practices do not only violate the oath of notary office, but can even be categorized as not well-intentioned notaries, who deliberately make false deeds, which lead to illegal acts.
\end{abstract}

\section{Keywords: Change, Minuta Deed, Notary}

\begin{abstract}
Abstrak
Penelitian ini bertujuan untuk menjelaskan perubahan minuta akta yang dilakukan oleh notaris secara sepihak tanpa sepengetahuan salah satu penghadap; metode penelitian yang digunakan dalam penelitian ini metode yuridis normatif. Teknik pengumpulan data dilakukan melalui penelitian kepustakaan. Data yang diperoleh dianalisis dengan menggunakan pendekatan kualitatif. Hasil penelitian menunjukkan bahwa masih ditemukan beberapa kasus yang menjerat notaris kedalam pengadilan, baik ranah perdata maupun pidana, yaitu putusan Putusan Mahkamah Agung RI Nomor.42/PDT.G/2013/PN.PBR, Putusan Mahkamah Agung RI Nomor.606/PDT/2017/PT.DKI, Putusan Mahkamah Agung RI Nomor 1003 K/PID/2015, dan Putusan Mahkamah Agung RI Nomor 1099 K/PID/2010, dalam putusan-putusan tersebut menyatakan bahwa masih ada notaris yang kurang hati-hati dalam melahirkan sebuah akta. Akibatnya, salah satu pihak mengalami
\end{abstract}


kerugian dalam hal ini notaris secara sengaja atau tidak disengaja bersama-sama dengan pihak/penghadap membuat akta dengan maksud dan tujuan untuk menguntungkan pihak atau penghadap tertentu saja atau merugikan penghadap yang lain. Hal ini menimbulkan ketidakpastian hukum bagi klien ataupun penghadap yang sengaja datang ke hadapan notaris untuk meminta bantuan dalam melakukan perbuatan hukum. Praktik demikian tidak hanya melanggar sumpah jabatan notaris, tetapi bahkan bisa dikategorikan notaris tidak beriktikad baik, yang secara sengaja membuat akta palsu, yang mengarah pada perbuatan melawan hukum.

\section{Kata kunci: Perubahan, Minuta Akta, Notaris}

\section{PENDAHULUAN}

Negara Republik Indonesia merupakan sebuah negara hukum (rechtstaat) berdasarkan pada Undang-Undang Dasar Negara Republik Indonesia Tahun 1945 (selanjutnya disebut UUD 1945), yang semua kekuasaannya tunduk kepada hukum yang telah ditetapkan. Sebagai suatu negara hukum, bahwa hukum di Indonesia memiliki kedudukan sangat tinggi didalam suatu pemerintahan dan demi perlindungan atau pengamanan bagi keperluan setiap individu. Hukum juga mengatur semua hubungan antar individu atau orang dengan kelompok atau masyarakat maupun individu dengan pemerintah dan hubungan antara individu atau perorangan . ${ }^{1}$

Menurut Gustav Radbuch, hukum harus mengandung 3 (tiga) nilai identitas yaitu, "Pertama, asas kepastian hukum (rechtmatigheid), asas ini meninjau dari sudut yuridis. Kedua, asas keadilan hukum (gerectigheit), asas ini meninjau dari sudut filosofis dimana keadilan adalah kesamaan hak untuk semua orang di depan pengadilan, dan yang ketiga adalah asas kemanfaatan hukum (zwechmatigheid atau doelmatigheid atau utility), asas ini meninjau dari sosiologis". ${ }^{2}$

Asas kepastian hukum merupakan "jaminan akan perlindungan hukum kepada para pihak, oleh sebab itu notaris juga berwenang untuk ketertiban, perlindungan, dan menjamin adanya suatu kepastian hukum, dalam halnya perubahan minuta akta yang dilakukan dengan notaris dan harus mendapat kepastian hukum, dan harus menjamin adanya ketertiban, ${ }^{3}$ terutama sekali dalam hal produk notaris yaitu pembuatan akta autentik dimana akta yang merupakan sebuah dokumen yang yang bisa memberi suatu kepastian untuk semua masyarakat".

Menurut Hans Kelsen tanggung jawab hukum adalah "seseorang bertanggung jawab secara hukum atas suatu perbuatan tertentu atau bahwa dia memikul tanggung jawab hukum". ${ }^{4}$ Tanggung jawab seorang notaris yaitu untuk mewujudkan keadilan bagi rakyat atau masyarakat salah satunya dalam hal pembuatan akta notaris. Mochtar Kusumaatmaja dan B.Arief Sidarta, mengatakan keadilan merupakan "unsur yang tidak bisa dipisahkan dari hukum sebagai perangkat asas dan kaidah yang menjamin kepastian hukum". 5

Notaris selaku pejabat umum yang memiliki kewenangan didalam pembuatan akta sebagai alat bukti yang sempurna dan notaris juga berwenang untuk memberikan

\footnotetext{
${ }^{1}$ Supriadi, 2008, Etika dan Tanggungjawab Profesi Hukum di Indonesia, Sinar Grafika, Jakarta, hlm.29.

${ }^{2}$ Sudarsono, 2007, Kamus Hukum Edisi Baru, Cetakan Kelima, Rineka Cipta, Jakarta, hlm.397.

${ }^{3}$ Doddy Noormansyah, HOLDING GAME, MERGER DAN PENEGAKAN HUKUM PERSAINGAN USAHA. Jurnal Hukum Litigasi, vol.07 no.1 edisi Februari 2006, hlm.10.

${ }^{4}$ Hans Kelsen, 2007, Teori Umum hukum dan Negara, Dasar-dasar Ilmu Hukum Normatif sebagai Ilmu Hukum Deskriptif-Empirik, BEE Media Indonesia, Jakarta, hlm.81.

${ }^{5}$ Mochtar Kusumaatmaja dan B.Arief Sidarta, 2000, Pengantar Ilmu Hukum, Suatu Pengenalan Pertama Ruang Lingkup Berlakunya Ilmu Hukum, Alumni, Bandung, hlm.52.
} 
pelayanan hukum pada publik atau masyarakat umum khusunya yang berhubungan dengan minuta akta atau dokumen atau arsip negara dan juga berhubungan dengan produk hukum di bidang keperdataan, sebuah dokumen yang menjadi produk dari notaris dan sesuai dengan prosedur-prosedur yang sudah di tetapkan maka dokumen tersebut menjadi sah dan sempurna sebagai alat bukti. ${ }^{6}$ Dokumen ataupun surat yang dijamin legalitas supaya tidak menjadi tumpah tindih pada pemenuhan kewajiban dan hak dan kemudian haruslah dibuat ke dalam bentuk akta autentik yang mana pembuatannya tersebut di buat oleh atau dihadapan pejabat umum yang berwenang.

Notariil akta adalah "suatu alat pembuktian yang penuh, terkuat, dan sempurna yang dapat menghindari terjadinya sengketa dan dapat menjamin kepastian hukum bagi setiap individu atau masyarakat". Mengenai minuta akta, dalam Pasal 1 angka 8 UndangUndang Nomor 2 Tahun 2014 tentang Perubahan atas Undang-Undang Nomor 30 Tahun 2004 tentang Jabatan Notaris ( selanjutnya disebut UUJN) menyebutkan bahwa "Minuta akta adalah asli akta yang mencantumkan tanda tangan para penghadap, saksi dan Notaris, yang disimpan sebagai bagian dari Protokol Notaris". Dari bunyi ketentuan diatas, dapat diambil kesimpulan dimana minuta ini merupakan "suatu akta yang dibuat dan dibaca oleh notaris dan ditandatangani oleh para penghadap, saksi-saksi, dan notaris, serta perubahan dan mungkin terdapat bukti-bukti lain yang dilakukan pada minuta akta. Pada sebuah minuta akta yang menjadi produk notaris berisi nomor, tanggal, bulan, tahun, dan jam akta tersebut dibuat. Kemudian, minuta akta yang telah dibuat dapat dicatat dalam repertorium".

Minuta akta juga berisi data diri atau keterangan-keterangan dari para penghadap dan dokumen-dokumen lain yang dibutuhkan untuk membuat akta tersebut. Setiap bulan minuta akta yang dibuat oleh notaris wajib dijilid menjadi satu buku yang berisi tidak lebih dari 50 akta dan pada setiap sampul bukunya harus dicatat total minuta akta, bulan, dan tahun pembuatannya. Dimana salinan akta yang dibuat tersebut harus sama persis isinya dengan minuta akta. Dan pembedanya hanya pada cap jempol, paraf, tanda tangan, dan perubahannya. Minuta akta juga dapat digunakan sebagai arsip negara, yang dapat digunakan apabila ada suatu perkara atau sengketa di kemudian hari. Oleh karena itu, minuta akta juga harus disimpan baik-baik dan dirawat oleh notaris. ${ }^{7}$

Pada Pasal 48 ayat (1) UUJN, menyebutkan larangan mengenai perubahan isi akta oleh notaris. Pasal ini berbunyi:

"Isi akta dilarang untuk diubah dengan:

a. diganti;

b. ditambah;

c. dicoret;

d. disisipkan;

e. dihapus; dan / atau

f. ditulis tindih."

Menurut Pasal 48 ayat (2) UUJN, yang berisi : "perubahan isi akta sebagaimana dimaksud pada ayat (1) huruf a, huruf b, huruf c, dan huruf d dapat dilakukan dan sah jika perubahan tersebut diparaf atau diberi tanda pengesahan lain oleh penghadap,

\footnotetext{
${ }^{6}$ Allamudin Al Faruq, PERLINDUNGAN NOTARIS DALAM PENGAMBILAN MINUTA AKTA DAN PEMANGGILAN PADA PERADILAN PASCA UNDANG-UNDANG NOMOR 2 TAHUN 2014. Jurnal Penelitian Hukum, vol. 2 no. 2 edisi juli 2015, hlm. 81.

${ }^{7}$ Cut Era Fitriyeni, TANGGUNG JAWAB NOTARIS TERHADAP PENYIMPANAN MINUTA AKTA SEBAGAI BAGIAN DARI PROTOKOL NOTARIS. Jurnal Ilmu Hukum, vol 14, no. 3 edisi desember 2012, hlm. 395.
} 
saksi, dan notaris." Perubahan ini boleh dilakukan jika akta belum ditandatangani oleh pihak penghadap. ${ }^{8}$

Kewenangan notaris untuk melakukan perubahan haruslah sejalan dengan peraturanperaturan yang ada, supaya akta masih bisa dijadikan alat bukti sempurna. Jikalau notaris tidak menjalakannya sesuai dengan ketentuan dan peraturan-peraturan yang ada, perbuatan notaris dikualifikasikan sebagai suatu perbuatan melawan hukum. Hal ini disebabkan dari tindakan dan kesalahan yang dilakukannya menyebabkan kerugian bagi orang atau pihak lain. Pasal 1365 KUH Perdata, menerangkan bahwa "tiap perbuatan yang melanggar hukum dan membawa kerugian kepada orang lain, mewajibkan orang yang menimbulkan kerugian itu karena kesalahan untuk menggantikan kerugian tersebut".

Pada kenyataannya ditemukan beberapa kasus yang melibatkan dan menjerat para notaris ke dalam pengadilan, dalam kasus ini tidak saja menjadi permasalahan ranah hukum perdata tetapi juga masuk ke dalam ranah hukum pidana, yaitu "putusan Putusan Mahkamah Agung RI Nomor.42/PDT.G/2013/PN.PBR, Putusan Mahkamah Agung RI Nomor.606/PDT/2017/PT.DKI, Putusan Mahkamah Agung RI Nomor 1003 K/PID/2015, dan Putusan Mahkamah Agung RI Nomor 1099 K/PID/2010, tindakan notaris pada putusan-putusan tersebut menyatakan bahwa masih ada notaris yang kurang hati-hati dalam mengambil tindakan dan mengabaikan peraturan yang terdapat dalam UUJN dalam melahirkan suatu akta. Hal ini menyebabkan timbul kesalahan, khususnya ketika seorang notaris melakukan perubahan pada minuta akta pasca salinan telah dikeluarkan. Akibat dari pelanggaran yang dilakukan oleh seorang notaris tersebut dapat menyebabkan kerugian bagi salah satu pihak, dimana notaris sudah lalai dalam melakukan tugasnya dan dilakukannya secara sengaja atau tidak sengaja, secara bersama-sama oleh pihak/penghadap yang membuat akta dengan tujuan dan maksud untuk menguntungkan salah satu pihak / penghadap atau merugikan penghadap yang lain. Peristiwa ini dapat menimbulkan ketidakpastian hukum bagi klien ataupun penghadap yang dengan sengaja datang dan menghadap notaris untuk meminta bantuan untuk melakukan perbuatan hukum. Praktik seperti ini bisa dikategorikan notaris tidak beriktikad baik dan notaris telah melanggar sumpahnya, dimana notaris yang secara sengaja membuat akta palsu, yang mengacu pada suatu perbuatan melawan hukum. Seharusnya notaris yang telah mempunyai wewenang untuk membuat dan melakukan perubahan pada akta bisa lebih hati-hati dalam melakukannya, yang harus sesuai dengan peraturan- peraturan dan telah ditetapkan".

Berdasarkan penjabaran yang sudah disampaikan pada latar belakang diatas, bahwa permasalahannya menarik untuk diteliti dan adanya suatu akibat yang didapat di dalam penulisan ini dimana renvoi yang dilakukan tidak sesuai dengan aturan yang berlaku oleh sebab itu akan dilakukan kajian mendalam pada penulisan ini yaitu, Bagaimana tanggung jawab notaris terhadap perubahan minuta akta yang dilakukannya secara sepihak tanpa sepengetahuan salah satu penghadap?

Metode penelitian yang digunakan dalam penelitian ini "yuridis normatif, pendekatan yang digunakan dalam penulisan adalah suatu pendekatan yang ada pada perundangundangan dan juga pendekatan konseptual. Analisis bahan hukum yang digunakan adalah pendekatan suatu kualitatif yang digunakan untuk menghasilkan suatu data

${ }^{8}$ Reinaldo Michael Halim, AKIBAT HUKUM BAGI NOTARIS DALAM PELANGGARAN PENGGANDAAN AKTA. Lex Et Societatis, vol. III no. 4 edisi mei 2015, hlm.99.

100 Jurnal IUS Kajian Hukum dan Keadilan 
deskriptif dengan tujuan untuk mendeskripsikan secara sistematis, faktual dan akurat. Teknik pengumpulan data dilakukan melalui penelitian kepustakaan".

\section{PEMBAHASAN}

\section{Tanggung Jawab Notaris Terhadap Perubahan Minuta Akta Yang Dilakukannya Secara Sepihak Tanpa Sepengetahuan Salah Satu Penghadap}

Setiap perbuatan apapun yang dibuat oleh masyarakat atau individu yang menjadi bagian didalam suatu aturan bagi masyarakat sosial atau invidu yang tidak akan terpisah dari apa yang dinamakan tanggungjawab. Demikian pula halnya dengan notaris, mempunyai tanggungjawab yang berat dalam menjalankan tugas jabatannnya. Dengan lahirnya Undang - Undang Jabatan Notaris Tahun 2014 bisa dikatakan bahwa sudah terjadinya suatu persatuan hukum di dalam pengaturan Notaris di Indonesia dan Undang-Undang Jabatan Notaris Tahun 2014 dimana undang - undang ini dapat menjadi sebagai alat ukur guna keabsahan atau kebenaran notaris didalam melaksanakan tugas atau tanggung jawab pada jabatannya dengan maksud apabila dilanggar maka akan mengakibatkan dampak hukum terhadap akta yang dibuat di hadapannya serta terhadap Notaris itu sendiri.

Berdasarkan Ketentuan Pasal 1 ayat (1) Undang-Undang Jabatan Notaris Nomor 30 Tahun 2014 menyatakan, "Notaris adalah Pejabat Umum yang berwenang untuk membuat akta autentik dan memiliki kewenangan lainnya sebagaimana dimaksud dalam Undang- Undang ini atau berdasarkan Undang- Undang lainnya".Sehubungan dengan jabatan notaris yaitu "suatu jabatan kepercayaan bagi masyarakat dan secara transparan yang sudah dijelaskan bahwa akta notaris mempunyai karakter yuridis yang individual atau tersendiri pada pembentukannya yang menggunakan lambang negara, dimana penggunaan lambang Negara Burung Garuda sebagai stempel dan cap pada aktanya, sebagai salah satu bukti adanya pelimpahan wewenang dari Negara bagi notaris dalam hal perbuatan hukum, serta sebagai salah satu alat bukti yang autentik didalam bentuk keabsahan formal dan untuk menjamin suatu kepastian hukum. Notaris selaku pejabat umum yang berwenang untuk membuat akta autentik tentang segalapenetapan, perjanjian, dan perbuatan yang diwajibkan oleh peraturan - peraturan yang berlaku dan/atau yang dimaksudkan untuk dicantumkan dalam akta autentik, dan untuk menjamin adanya suatu kepastian pada salinan, tanggal, kutipan pembuatan akta dan memberi grosse, selama pembuatan aktanya itu tidak diperintahkan kepada pejabat lain atau orang lain yang ditetapkan oleh undang-undang". ${ }^{9}$

Dalam pembuatan akta autentik maka para pihak pasti membutuhkan bantuan atau pelayanan dari seorang notaris dan memiliki nilai kepercayaan yang tinggi dari masyarakat, karena setiap subjek hukum pasti akan selalu membutuhkan sosok yang bisa diandalkan secara kepercayaan, hukum dan dimana tanda tangan atau segel yang diberikan dapat menjadi atau bisa memberikan jaminan dan bukti yang kuat untuk suatu perjanjian dan apa yang telah di buat dapat menjadi suatu bukti yang autentik di kemudian hari apabila terjadinya suatu sengketa. Dan para penghadap mengharapkan agar tindakan atau suatu perbuatannya itu dapat dirumuskan ke dalam suatu akta autentik, dimana hal tersebut sesuai dengan kewenangan yang dimilii oleh seorang notaris. Selanjutnya notaris tersebut membuat akta, atas keinginan atau permintaan

\footnotetext{
${ }^{9}$ Pingkan Sundah, TINJAUAN YURIDIS TERHADAP TIDAK DILAKSANAKAN KEWAJIBAN JABATAN NOTARIS MENURUT UNDANG-UNDANG NO.2 TAHUN 2014. Lex et Societatis, vol.II no.4 edisi mei 2014, hlm.35.
} 
dari pihak penghadap atau para pihak, dalam hal ini sudah terjadinya suatu hubungan hukum antara seorang notaris dengan para pihak atau penghadap karena sudah adanya suatu landasan yang diberikan dan menimbulkan suatu perbuatan atau hubungan hukum bagi kedua belah pihak.

Notaris dalam menjalankan jabatannya, "sebelum menentukan pokok perjanjian dalam akta yang ditandatangani oleh penghadap atau para pihak, notaris wajib menanyakan hal-hal yang akan dituangkan dalam isi aktanya. Menentukan pokok perjanjian berarti menentukan dasar dari sebuah kepentingan para pihak yang diharapkan akan menjadi pokok dari suatu perjanjian. Dasar dari perjanjian harus dapat dirumuskan dengan penuh kehati - hatian dan akurat karena rumusan tersebut menentukan kepastian dari pelaksanaannya. Penetapan dari suatu hak dan kewajiban para pihak atau penghadap harus dapat ditetapkan secara seimbang, adil dan rasional. Bentuk yang tidak seimbang mengakibatkan dapat terjadinya hal - hal yang merugikan dan tidak membawa keuntungan bagi salah satu pihak".

Pasal 1 ayat (8) Undang-Undang Jabatan Notaris Nomor 30 Tahun 2014 menjelaskan bahwa, "minuta akta adalah asli akta yang mencantumkan tanda tangan para penghadap, saksi, dan Notaris, yang disimpan sebagai bagian dari protokol notaris". Notaris sebagai Pejabat Umum dalam menjalankan jabatannya mempunyai kewajiban yang telah ditentukan di dalam Pasal 16 Undang-Undang Jabatan Notaris Nomor 30 Tahun 2014, dimana kewajiban notaris yang salah satunya yang tercantum di dalam ketentuan Pasal 16 ayat (1) huruf a Undang-Undang Jabatan Notaris Nomor 30 Tahun 2014 menyebutkan Notaris berkewajiban " bertindak amanah, jujur, saksama, mandiri, tidak berpihak, dan menjaga kepentingan pihak yang terkaid dalam perbuatan hukum". Dalam Pasal 16 ayat (1) huruf d Undang-Undang Jabatan Notaris Nomor 30 Tahun 2014, mengartikan bahwa notaris berkewajiban "mengeluarkan grosse akta, salianan akta, atau kutipan akta berdasarkan minuta akta".

Pasal 48 Undang-Undang Jabatan Notaris Nomor 30 Tahun 2014 ayat (1) menjelaskan bahwa "isi akta dilarang untuk diubah dengan: diganti, ditambah, dicoret, disisipkan, dihapus; dan/atau ditulis tindih". Dalam ayat (2) dijelaskan bahwa, "perubahan isi Akta tersebut dalam ayat 1 huruf a, b, c, dan d dapat dilakukan dan sah jika perubahan tersebut diparaf atau diberi tanda pengesahan lain oleh penghadap, saksi, dan Notaris. Pelanggaran atas ayat 1 dan 2, mengakibatkan suatu Akta hanya mempunyai kekuatan pembuktian sebagai akta di bawah tangan dan dapat menjadi alasan bagi pihak yang menderita kerugian untuk menuntut penggantian biaya, ganti rugi, dan bunga kepada Notaris", dan pada Pasal 48 ayat (3) Undang-Undang Jabatan Notaris Nomor 30 Tahun 2014 juga menjelaskan "Pelanggaran terhadap ketentuan sebagaimana dimaksud pada ayat (1) dan ayat (2) mengakibatkan suatu Akta hanya mempunyai kekuatan pembuktian sebagai akta di bawah tangan dan dapat menjadi alasan bagi pihak yang menderita kerugian untuk menuntut penggantian biaya, ganti rugi, dan bunga kepada Notaris". Maka jika notaris melakukan perubahan pada minuta akta pasca salinan telah dikeluarkan dan notaris melakukan perubahan tersebut di luar dari ketentuan yang telah disebutkan dalam Undang-Undang Jabatan Notaris Nomor 30 Tahun 2014, terhadap bentuk formal dalam sebuah akta yang dapat menyebabkan akta tersebut cuma memiliki kekuatan pembuktian seperti akta di bawah tangan dan akan mengakibatkan kerugian untuk salah satu pihak. Apabila notaris membuat perubahan terhadap substansi akta tanpa adanya tanda pengesahan atau diparaf maka, aktanya 
hanya memiliki kekuatan pembuktian sebagai akta di bawah tangan dan menyebabkan salah satu pihak mengalami kerugian, dan pihak yang merasa di rugikan tersebut bisa menggugat notaris untuk mengganti kerugian yang telah dialaminya, penggantian atas perbuatan notaris tersebut dapat berbentuk bunga, ganti rugi dan penggantian biaya. ${ }^{10}$

Sejak dikeluarkannya Pasal 48 Undang-Undang Jabatan Notaris Nomor 30 Tahun 2014, "ini saat notaris membacakan akta dan ternyata menemukan kesalahan kesalahan dalam bentuk apapun baik itu pada awal atau akhir akta tersebut, maka yang harus langsung dilakukan oleh pihak notaris" ialah "pertama, langsung melakukan perubahan atas rancangan akta notaris dengan melakukan cetak ulang jika penghadap masih ada dan ada perlengkapan kantor yang mendukung, yang kedua jika penghadap sudah tidak ada maka pihak notaris wajib untuk segera menghubungi para penghadap untuk membuat perbaikan akta karena sebuah perbaikan pada akta akan dianggap sah apabila adanya tanda pengesahan atau paraf dari para penghadap, saksi dan pihak notaris itu sendiri".

Kesalahan yang dilakukan oleh notaris dalam Pasal 48 Undang-Undang Jabatan Notaris Nomor 30 Tahun 2014, tentang "perubahan terhadap isi akta dimana jika notaris pada saat membuat akta tidak sama atau tidak sesuai dengan apa yang ada di dalam peraturan perundang-undangan yang berlaku, maka dalam keadaan ini perbuatan notaris tersebut bisa dikualifikasikan sebagai perbuatan melawan hukum", yang mana telah diatur didalam Pasal 1365 Kitab Undang-Undang Hukum Perdata, menyebutkan bahwa "tiap perbuatan yang melanggar hukum dan membawa kerugian kepada orang lain, mewajibkan orang yang menimbulkan kerugian itu karena kesalahan untuk menggantikan kerugian tersebut".

Pada Pasal 51 ayat (1) Undang-Undang Jabatan Notaris Nomor 30 Tahun 2014, menerangkan bahwa "notaris berwenang untuk membetulkan kesalahan tulis dan/ atau kesalahan ketik yang terdapat pada minuta akta yang telah ditanda tangani". Pada ayat (2) dijelaskan bahwa "pembetulan sebagaimana dimaksud pada ayat (1) dilakukan di hadapan penghadap, saksi, dan Notaris yang dituangkan dalam berita acara dan memberikan catatan tentang hal tersebut pada minuta akta asli dengan menyebutkan tanggal dan nomor akta berita acara pembetulan". Dalam ayat (3) juga dijelaskan, "salinan akta berita acara sebagaimana dimaksud pada ayat (2) wajib disampaikan kepada para pihak". Apabila terhadap salinan akta yang tidak sama bunyinya dengan dengan minuta aktanya, maka salinan akta tersebut harus ditarik kembali oleh notaris untuk dimusnahkan ataupun pihak yang bersangkutan menghadap kepada notaris yang membuat salinan akta, untuk meminta diperbaiki.Agar tidak terjadinya kesalahan - kesalahan dari minuta akta, dan salinan akta yang dibuat oleh notaris didasarkan ketentuan Pasal 1 ayat (9) Undang-Undang Jabatan Notaris Nomor 30 Tahun 2014, yang menjelaskan bahwa "Salinan Akta adalah salinan kata demi kata dari seluruh akta dan pada bagian bawah salinan akta tercantum frasa 'diberikan sebagai salinan yang sama bunyinya".

"Setelah notaris menandatangani akta yang telah dibuatnya dengan dihadiri oleh penghadap/kuasanya dan saksi-saksi notaris, maka biasanya notaris tidak secara langsung membuat salinan akta berlandaskan pada minuta yang sudah ditandatangani. Dalam melakukan ini notaris tidak hanya melakukannya sendiri melainkan dibantu oleh pegawai - pegawainya, notaris membetulkan dengan mencatat perubahan yang ada pada

\footnotetext{
${ }^{10}$ Salim, 2018, Peraturan Jabatan Notaris, Sinar Grafika, Jakarta, hlm.236.
} 
minuta akta pada selembar kertas, yang dapat terdiri dari penambahan, pencoretan dan penggantian, hal mana perubahan ini ditulis disisi kiri akta. Perubahan ini lalu dimasukkan ke dalam salinan akta yang hendak dibuat dan mengakibatkan tidak akan ada lagi perubahan - perubahan lain dalam minuta akta yang sebelumnya".

Terkait salinan akta yang tidak sesuai bunyinya seperti pada minuta akta, bahwa kelalaian ini adalah "suatu kesalahan yang dilakukan notaris pada saat membuat akta yang mengakibatkan pihak lain mendapatkan kerugian dan merupakan suatu perbuatan melawan hukum yang disebabkan kelalaian yang dilakukan oleh notaris. Notaris dalam membuat salinan akta yang bunyinya tidak sesuai pada minuta akta aslinya, bisa dikatakan bahwa notaris tersebut telah membuat suatu kesalahan terhadap jabatannya yang mana di dalam melakukan tugasnya seorang notaris harus peka terhadap kewajibannya sendiri yaitu harus bertindak amanah, jujur, saksama, mandiri, tidak berpihak dan menjaga kepentingan pihak yang terkait dalam perbuatan hukum serta adanya rasa kehati-hatian dan tanggung jawab dalam menerbitkan sebuah akta. Dan kesesuai pada suatu salinan akta dan minuta akta harus bisa tercapai. Dimana hal ini dibuat untuk menghindari terjadinya suatu kekhilafan yang dapat menimbulkan terjadinya suatu masalah di kemudian hari, dan notaris harus bisa dan memberi suatu kepastian hukum terhadap apa yang telah dibuat olehnya".

Dalam melakukan perubahan salinan akta yang telah dikeluarkan harus mendatangkan kembali para pihak dengan membuat akta berita acara pembetulan tentang apa yang hendak dirubah dan bersamaan setelah dibacakan maka selanjutnya ditandatangani oleh para pihak. ${ }^{11}$ Akan tetapi adakalanya para pihak sulit untuk dihubungi dan sulit untuk datang menghadap notaris akibatnya akta tersebut masih dalam keadaan penulisan dan kalimat yang salah. Dalam hal ini tidak ada solusi lain selain menunggu para pihak untuk dapat didatangkan kembali. Menyikapi hal ini apabila penghadap tidak dapat dihubungi menggunakan cara apapun maka kembali lagi ke sikap masing-masing Notaris apabila berpaham jangan melakukan apabila tidak ada diaturnya, danhal itu tidak harus dilakukan.

Perlunya peranan notaris untuk menciptakan "perlindungan hukum dan kepastian hukum untuk masyarakat atau publik yang bersifat preventif dimana notaris harus bisa bersifat menghindari terjadinya suatu problematika hukum, dengan melahirkan sebuah akta autentik yang dibuat dihadapannya yang mereka dengan status hukum, kewajiban dan hak seseorang dalam hukum yang mana berfungsi untuk alat bukti yang sangat sempurna di mata pengadilan apabila terjadi sengketa atas kewajiban dan haknya". ${ }^{2}$

Tanggung jawab dalam arti hukum merupakan "tanggung jawab yang benar-benar terikat dengan suatu kewajiban dan haknya. Terdapat dua istilah yang merujuk kepada pertanggung-jawaban hukum". "Pertama, liability yang merupakan sebuah kata hukum yang luas yang menunjuk hampir semua karakter risiko atau tanggung jawab, yang pasti, yang bergantung atau yang mungkin mencakup semua karakter hak dan kewajiban secara aktual atau potensial seperti ancaman, kejahatan, biaya kerugian,dan kondisi yang menciptakan tugas untuk melaksanakan Undang-undang. Kedua, responsibility yang merupakan sesuatu yang bisa dipertanggung-jawabkan atas suatu kewajiban, dan termasuk putusan, kemampuan, ketrampilan, dan kecakapan mencakup kewajiban bertanggung jawab atas undang-undang yang dilaksanakan. Pada istilah liability lebih

\footnotetext{
${ }^{11}$ Fredian Tonny Nasdian, 2015, Sosiologi Umum, Yayasan Pustaka Obor Indonesia, Jakarta, hlm.111.

${ }^{12}$ Sjaifurrachman, 2011, Aspek Pertanggungjawaban Notarisdalam Pembuatan Akta, Mandar Maju, Bandung, hlm. 7 .
}

104 Jurnal IUS Kajian Hukum dan Keadilan 
merujuk pada pertanggung-jawaban hukum, dimana tanggung gugat karena kesalahan yang dilakukan oleh subyek hukum, sedangkan istilah responsibility lebih merujuk pada pertanggung-jawaban politik". ${ }^{13}$

Pada saat memberikan pelayanan seorang notaris yang profesional bertanggung jawab terhadap pribadi atau kepada publik. Dalam artian bertanggung jawab terhadap dirinya sendiri yaitu "seorang notaris harus bertindak secara moralitas, profesionalitas, dan intergritas demi kehidupannya.. Sedangkan bertanggung jawab kepada publik yaitu, seorang notaris haru bersedia memberikan pelayanan terbaik kepada para pihak tanpa membedakan juga berani untuk menanggung seluruh akibat - akibat yang akan terjadi dari jasanya tersebut, baik itu secara kesengajaan atau karena kelalaiannya". ${ }^{14}$ Tanggung jawab notaris di dalam Undang - Undang Jabatan Notaris Tahun 2014, artinya notaris harus bisa untuk berkomitmen pada ketentuan - ketentuan hukum ketika melaksanakan suatu tugas dan kewajibannya, artinya segala perbuatan yang dilakukan oleh seorang notaris ketika melakukan tugas dan kewajibannya wajib mempertanggung jawabkan secara hukum, termasuk semua konsekuensi dalam pemberian sanksi - sanksi hukum atas pelanggaran norma - norma hukum yang menjadi pedomannya. Tanggung jawab notaris dalam arti hukum juga terkait dengan hak dan kewajiban dimana hak dan kewajiban notaris adalah notaris berkewajiban sebagaimana yang telah dijelaskan dalam Pasal 16 Undang - Undang Jabatan Notaris Tahun 2014, notaris juga berkewajiban untuk memberikan jasa eksklusif bagi penghadap dan notaris berhak atas pembayaran honorium setelah menyelesaikan salinan akta atas permintaan penghadap, dan notaris wajib membayar ganti rugi atas kelalaian atau kesengajaan yang dilakukan oleh dirinya sendiri.

Membuat sebuah perjanjian dengan maksud untuk semata-mata mengambil keuntungan dari salah satu pihak hanya akan menjadi kesalahan notaris yang akan menyebabkan akibat hukum untuk notaris itu sendiri. Didalam pembuatan sebuah akta autentik, notaris wajib bertanggung jawab pada segala pelanggaran atau kesalahan yang sengaja dibuat oleh seorang notaris pada saat pembuatan akta. Sebaliknya bila unsur pelanggaran dan kesalahan disebabkan oleh para penghadap itu sendiri. Maka notaris tidak bisa diminta pertanggungjawabannya, sebab notaris hanya menjalankan tugasnya untukmencatat apa saja yang disampaikan sama para pihak dandimuatkan dalam sebuah akta.

Jika dalam praktik notaris terjadi kesalahan melakukan perubahan terhadap isi akta yang mana hal tersebut tidak selaras dengan ketentuan - ketentuan yang berlaku, "maka tindakan notaris dalam hal ini sudah menyebabkan kerugian bagi pihak-pihakyang namanya tercantum di dalam akta, yang mana para penghadap mengharapkan akta yang dibuat oleh notaris tersebut memiliki kekuatan yang sempurna, akan tetapi akibat dari notaris yang sudah melanggar ketentuan Undang- Undang Jabatan Notaris Tahin 2014, maka akta tersebut menjadi akta yang tidak sempurna dan memiliki kekuatan pembuktian menjadi akta dibawah tangan. Karena tindakan notaris ini tidak saja menyebabkan akta yang sepatutnya sebagai akta autentik malah menjadi akta di bawah tangan dan batal demi hukum, karena kesalahan tersebut notaris patut menerima akibat hukum yang akan diberikan. Dimana akibat hukum untuk notaris telah melakukan suatu pelanggaran terhadap jabatannya yaitu, bisa berupa sanksi. Sanksi

\footnotetext{
${ }^{13}$ Ridwan H.R, 2006, Hukum Administrasi Negara, Raja Grafindo Persada, Jakarta, hlm. 56.

${ }^{14}$ Abdul Kadir Muhammad, 2011, Etika Profesi Hukum, Citra Aditya Bakti, Bandung, hlm. 60.
} 
tersebut dapat berbentuk tindakan/ perbuatan. Sanksi juga merupakan suatu aturan hukum yang dicantumkan dalam setiap peraturan - peraturan yang berlaku dan aturan hukum tidak bisadijalankan tanpa adanya sanksi. Dikarenakan sanksi merupakan sebuah paksaan yang bisa membuat rasa jera bagi pelanggarnya dan yang melanggarnya mengetahui bahwa tindakan dan perbuatan yang dilakukannya itu tidak sesuai dengan aturan hukum yang ada. Sanksi yang diberikan kepada notaris bermaksud agar notaris tidak lagi melakukan pelanggaran dan bisa melindungi publik atau masyarakat dari tindakan -tindakan yang melanggar hukum yang dilakukan oleh notaris itu sendiri dan menimbulkan kerugian, jadi semua yang dilakukan notaris harus selaran sengan aturan - aturan yang ada. Sanksi juga bermaksud untuk melindungi kedudukan atau harkat martabat dan jabatan notaris sebagai jabatan kepercayaan bagi setiap masyarakat".

Tanggung jawab notaris disini, "notaris harus mengganti rugi atas kerugian yang dialami oleh pihak penghadap. Akan tetapi bukan hanya tanggung jawab dari notaris yang diminta, tanggung jawab dari pihak penghadap juga diperlukan, karena notaris yang melakukan tugasnya tidak sesuai dengan undang-undang bukan hanya karena kemauan dari notaris itu sendiri tetapi terkadang karena adanya paksaan atau rasa iba dari pihak penghadap itu sendiri".

Penjelasan yang terdapat di dalam Undang- Undang Jabatan Notaris Tahun 2014, membuktikan bahwa notaris hanya sekedar cuma bertanggung jawab atas formalitas pada suatu akta autentik dan tidak pada materi akta autentik tersebut. Oleh sebab itu menuntut notaris untuk bisa berperilaku adil dan tidak berpihak pada salah satu pihak atau penghadapdan memberikan nasihat hukum untuk para penghadap yang memerlukan arahan hukum kepada notaris yang berkaitan. Seiring dengan hal tersebut maka Notaris bisa diminta pertanggung jawabkan berdasarkan kebenaran materiil pada suatu akta apabia petunjuk hukum yang diberikannya ternyata di waktu ke depan adalah sesuatu yang lalai atau suatu kekeliruan.

Pihak yang menganggap dirugikan karena kesalahan ketik pada minuta akta yang disebabkan oleh pihak notaris maka "bisa mengajukan gugatan perdata yang berdasarkan pada perbuatan melanggar hukum kepada pengadilan negeri terhadap notaris yang sudah melakukan kesalahan dan agar notaris bisa dijatuhkan sanksi perdata yang berupa ganti kerugian, penggantian biaya dan bunga, sebagaimana dimaksud dalam Pasal 1365 Kitab Undang - Undang Hukum Perdata. Pasal 1365 Kitab Undang - Undang Hukum Perdata”, yang berbunyi bahwa "tiap perbuatan yang melanggar dan membawa kerugian kepada orang lain, mewajibkan orang yang menimbulkan kerugian itu karena kesalahnnya untuk menggantikan kerugian tersebut" karena kerugian yang disebabkan oleh suatu perbuatan melawan hukum tergolong ke dalam golongan kerugian yurisprudensi, materil, juga kerugian immateriil, yang dapat dinilai dengan uang. ${ }^{15}$

\section{SIMPULAN}

Notaris merupakan pejabat umum yang berwenang untuk membuat akta autentik. Jabatan seorang notaris juga merupakan sebuah jabatan yang terhormat karena jabatan notaris diibaratkansebagai jabatan kepercayaan secara personal karena jabatan kepercayaan inilah notaris menjadi orang yang dipercaya atau yang beriktikat baik oleh khalayak ramai dalam hal dalam pembuatan akta sebagai alat bukti yang sempurna. Kesalahan yang disebabkan oleh seorang notaris pada saat perubahan akta dimana

${ }^{15}$ Munir Fuadi, 2010, Perbuatan Melawan Hukum, Citra Aditya Bakti, Bandung, hlm.13. 
seharusnya dilakukan dengan cara mengganti, menambah, mencoret atau menyisipkan kata dan hanya boleh dilakukan pada isi akta saja, dan perubahan akta yang dianggap sah apabila telah diberi tanda paraf atau tanda pengesahan lain yang dilakukan oleh penghadap, saksi, dan notaris. Tetapi yang terjadi di lapangan malah sebaliknya tidak sesuai dengan peraturan yang ada.

Dimana seharusnya salinan akta notaris mempunyai kedudukan sebagai alatbukti yang sempurna malah sebaliknya yaitu menjadi alat bukti yang tidak sempurna yang disebabkan salinan akta tidak sama bunyinya dengan minuta aktanya, menyebabkan saliana akta tidak dapat memenuhi syarat formil dan materiil pada proses pembuatan akta. Oleh karena itu menyebabkan salinan akta tersebut dapat dinyatakan batal demi hukum. Tanggung jawab notaris karena perbuatannya dalam melakukan perubahan pada isi akta notaris tanpa sepengetahuan salah satu pihak atau penghadap, dan notaris tersebut dapat diberikan hukuman karena tindakannya tersebut telah mengandung unsur - unsur kesengajaan atau kelalaian di dalam pembuatan akta autentik yang mana keterangan tentang isinya tidak sesuai. Maka notaris dapat diberikan sanksi yang berupa ganti kerugian, penggantian biaya, dan bunga, terhadap perbuatan yang telah dilakukannya dengan melakukan penyalahgunaan terhadap wewenang yang telah diberikan maka notaris yang sudah mempunyai nilai kepercayaan yang tinggi dari masyarakat malah menjadi tidak dipercaya lagi dan juga dapat menimbulkan akibat tidak lagi ada percayaan untuk notaris - notaris yang lain dari masyarakat.

\section{DAFTAR PUSTAKA}

\section{Buku}

Abdul Kadir Muhammad, (2011), Etika Profesi Hukum, Citra Aditya Bakti, Bandung.

Fredian Tonny Nasdian, (2015) Sosiologi Umum, Yayasan Pustaka Obor Indonesia, Jakarta.

Hans Kelsen, (2007), Teori Umum Hukum dan Negara, Dasar-dasar Ilmu Hukum Normatif sebagai Imu Hukum Deskriptif-Empirik, BEE Media Indonesia, Jakarta.

Mochtar Kusumaatmaja dan B.Arief Sidarta, (2000), Pengantar Ilmu Hukum, Suatu Pengenalan Pertama Ruang Lingkup Berlakunya Imu Hukum, Alumni, Bandung.

Munir Fuadi, (2010), Perbuatan Melawan Hukum, Citra Aditya Bakti, Bandung

Ridwan H.R, (2006), Hukum Administrasi Negara, Raja Grafindo Persada, Jakarta.

Salim, 2018, Peraturan Jabatan Notaris, Sinar Grafika, Jakarta.

Sjaifurrachman, (2011), Aspek Pertanggungjawaban Notarisdalam Pembuatan Akta, Mandar, Bandung.

Sudarsono, (2007), Kamus Hukum Edisi Baru, Cetakan Kelima, Rineka Cipta, Jakarta.

Supriadi, (2008), Etika dan Tanggungjawab Profesi Hukum di Indonesia, Sinar Grafika, Jakarta.

Journal dan karya ilmiah lain

Allamudin Al Faruq, Perlindungan Notaris dalam Pengambilan Minuta Akta dan Pemanggilan pada Peradilan Pasca Undang-Undang Nomor 2 Tahun 2014, 
Jurnal Penelitian Hukum, Vol. 2, No. 2, Edisi Juli 2015, hlm. 81.

Cut Era Fitriyeni, Tanggung Jawab Notaris Terhadap Penyimpanan Minuta Akta Sebagai Bagian Dari Protokol Notaris, Jurnal Ilmu Hukum, Vol 14, No. 3, Edisi Desember 2012 , hlm. 395.

Doddy Noormansyah, Holding Game, Merger dan Penegakan Hukum Persaingan Usaha, Jurnal Hukum Litigasi, Vol.07, No.1, Edisi Februari 2006, 10.

Reinaldo Michael Halim, Akibat Hukum Bagi Notaris dalam Pelanggaran Penggandaan Akta, Lex Et Societatis, Vol. III, No. 4, Edisi Mei 2015, 99.

Pingkan Sundah, Tinjauan Yuridis Terhadap Tidak Dilaksanakan Kewajiban Jabatan Notaris Menurut Undang-Undang No.2 Tahun 2014", Lex et Societatis, Vol.II, No.4, Edisi Mei 2014, 35.

\section{Peraturan Perundang-undangan}

Kitab Undang-Undang Hukum Perdata

Undang-Undang Nomor 2 tahun 2014 tentang Perubahan atas Undang-Undang Nomor 30 Tahun 2004 Tentang Jabatan Notaris. 